\title{
ACQUISITION OF KOSA KATA BAHASA KARO \\ OF A FOUR YEAR KARONESE CHILD
}

AN ARTICLE.

Submitted in Partial Fulfillment of the Requirements for the Degree of Sarjana Pendidikan

By:

Endamya Bevi Nesra Barus

Registration Number: 2143220010

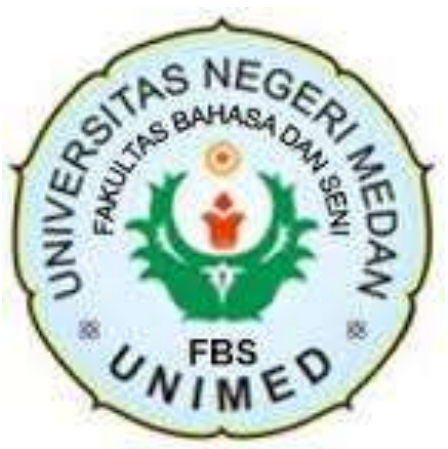

ENGLISH AND LITERATURE DEPARTMENT

FACULTY OF LANGUAGES AND ARTS STATE UNIVERSITY OF MEDAN

2021 
ARTIKEI.

ACQUISITION OF KOSA KATA BAHASA KARO OF A FOUR YEAR KARONESE CHIL.D

Disusum dan Diajukan olch.

Endamya Bevi Nesra Br Barus NIM. 2143220010

Telah diverifikasi dan dinyatakan mernenuhs syarar

untuk diumgah pado jumal ontine

Medan. Jamuari 202

Menyctujul

Dosen Pembimbiny

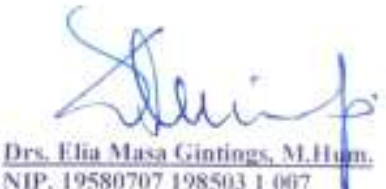

Dikeciahum alch.

Ka. Program Studi Sastra Ingerix

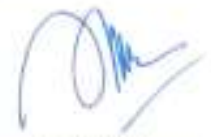

fuli Rachmadani Hasihuan, S. . M.Ifux NIP. 198207112008012008 


\title{
Acquisition of Kosa Kata Bahasa Karo of a Four Year Karonese Child.
}

\author{
Endamya Bevi Nesra Barus, Elia Masa Gintings \\ Universitas Negeri Medan
}

\begin{abstract}
This study analyzed the acquisition of kosa kata Bahasa Karo of a four year old Karonese Child. The instrument of collecting data is by voice recording of child in his daily activity. Particular attention is seeing aspects that affect child's acquisition as defined by using theory of Skinner, Behaviorist Theory. The result show that the child acquired 5 words of noun, 3 words of verb, 5 words of adjective, 2 words of adverb, 2 words of pronoun, 1 word of preposition, 1 word of conjunction, and 6 words of interjection. There are 2 aspects that affect child's acquisition namely social interaction with his environment and imitation from people around him.
\end{abstract}

Keywords: Child's Acquisition Word, Skinner Theory, Karonese Child. 


\section{INTRODUCTION}

Language is a system of communication by speaking, writing, or any of the different systems of communication use. The study of language Acquisition by children is very interesting. Learning to talk is more complicated than learning to walk (Clark, 2003). Talking plays a major role in social communication and demands a grasp of all the local conversation of use in each speech community.

There are various ways of acquiring language for children. According to Van Patten (2015) First language acquisition research in the early 1960s very quickly began to demonstrate that children could not possibly internalize a linguistic system according to the tenets of operant conditioning. The linguistic system was far too complex, and children's utterances showed evidence of processes beyond imitation and analogy. Instead, researchers began to argue that children bring an innate facility for language learning to the task of language acquisition. This facility was unaffected by the kinds of conditioning that were the basis of behaviorism. For example, children produce utterances that they could not have heard in the input, like Don't giggle me and I love cut-upped eggs. They also acquire very complex rules that could not have been learned through mere imitation or analogy. Children can interpret the questions such as When did Billy say he hurt himself? as having two possible answers (while he was skateboarding or He told us while we were eating dinner).

According to Clark (2003) as children learn to talk, they go through a series of stages beginning of infancy when they are unable to converse and do not yet understand any language. They go from bubbling at seven to ten months old, to producing their first recognizable words six to twelve months later. Then, within a few months, they combine words and gesture and produce their first word combination around age two. This is followed by the production of ever more complex, adult like utterances, as they become active participants in conversation, taking turns and making appropriate contributions.

Generally, someone's language are affected by social factor. Social factor has the most influence of someone's language such as family and society. Family is the important factor in someone's language. Society or environment also gives influence in someone's language, society will give someone chance in acquiring language. If someone has a good relation is environment, it will give positive impact in acquiring language, increase the motivation and low anxiety of acquiring language. Most people believe that children are better than adult when trying to learn new language. According to Stenberg (1993) factors involved in language acquisition can be divided into psychological and the social. Under 
psychological we shall consider the types of situation and his interaction in acquiring new language.

Clark (2003) state that their acquisition could also be affected by social interaction and cognitive development. Factors like these could also determine whether language-learners follow the same path, detect and use the same patterns, and make the same inferences about meanings during acquisition.

a. Psycholinguistics

Scovel (1998) defines psycholinguistics as the use of language and speech as a window to the nature and structure of the human mind. Talking about language and human mind will not be separated from the study of psycholinguistics and neurobiological that enable human to acquire, use and understand language. Psycholinguistics sees language as a process which involves the comprehension, production, and acquisition of language. According to Clark and Clark in (1977) psycholinguist of language or psycholinguistics is substantively concerned with two skills. These skills are speaking and listening and their acquisition. Then it consists of three basic broad processes as comprehension, production, and acquisition. The field of psycholinguistic by Clarks' statement consists of human ability and their comprehension in acquiring and producing language.

b. Language

Language is a system of communication by speaking, writing, or any of the different systems of communication use. The study of language Acquisition by children is very interesting. Learning to talk is more complicated than learning to walk (Clark, 2003). Language acquisition is the process whereby children achieve a fluent control of their native language (Varshney, 2003). Talking plays a major role in social communication and demands a grasp of all the local conversation of use in each speech community.

c. Vocabulary

According to Hatch and Brown (2001) vocabulary is a list of set of word for a particular language or a list or a set of words that individual speakers of a language might use. Vocabulary is the collection of words that an individual knows. Vocabulary can be defined as the words someone must know to communicate effectively; words in speaking(expressive vocabulary) and words in listening ( receptive vocabulary). 
1. Noun

Noun is the name of thing or subject.

2. Adjective

Adjective is the name of qualities of the things. It is the word used to qualify noun and pronoun.

3. Verb

Verb is a word that represents an action or state of being. A verb is the essential part of the predicate of sentences.

4. Adverb

An adverb is a part of speech that provides greater information or description of a verb, adjective, another adverb.

d. Child Language

Language is the tool of our communication; we need language to communicate with others. At birth we cannot speak or understand the speech. Eve V Clark (2003) explained that but babies are not born talking. They learn language, starting immediately from birth. What do they learn? They need sound and words, meaning and constructions. They need to know what to use where and when, how to integrate language with other modes of communication. Furthermore, Eve V Clark (2003) stated that when children learn first language, they could build on preexisting notions of what to represent with language as well as prior notions of communication.

e. Language Acquisition

Language acquisition begins very early in human's life. According to Towell (1994) language acquisition is the process by which a person learns language. It is called acquisition because some linguists believed that development of the first language in a child is a special process.

f. Behaviorist Theory (Imitation and reinforcement)

Skinner (2013:1) says that children acquire language by imitating the speech of others. When a child produces words successfully and they receive praise and encouragement, they subsequently are motivated to repeat the behavior. Based on the quotation, the researcher concludes that children will be able to imitate people's language around them; even they do not understand grammatical yet. 


\section{METHODOLOGY}

This research is defined to find out the Acquisition of Kosa Kata Bahasa Karo Of A Four Year Old Karonese Child. This analysis based on the Ttheory of Matthew B. Miles. He proposes states that qualitative data are as source of well-grounded, rich description and explanation of human process. With qualitative data, one can preserve chronological flow; see which events led to which consequence, and derive fruitful explanation. The scope of this study is limited to the acquisition of Kosa Kata Bahasa Karo of a Four Year Old Karonese Child named Beryl Ibrena Barus and aspect that influence the acquisition. In this research, the writer used descriptive qualitative method; collecting, identifying, classifying data, and drawing conclusion.

\section{FINDING AND DISCUSSION}

The data was acquired showed significant developmental differences in the process of children's language acquisition. The data that Beryl Ibrena Barus acquired so many, for analyzed kind of words : noun 5 words, verb 3 words, adjective 5 words, adverb 2 words, pronoun 2 words, preposition 1 words, conjunction 1 word, interjection 6 words. From this research, the researcher found some parts of speech by Karonese child aged four years old. Although he reached aged four but He still difficult to use Bahasa Karo in daily language. When he started to use Bahasa Karo, He would mix the language with Bahasa Indonesia, even we talked with him by using Bahasa Karo, He would answer by using Bahasa Indonesia. When we asked him to imitate what we are talking about, he would imitate our language. This finding is related to Wahyuni's research. She researched children aged 1-3 years old. She found that children at that aged acquired noun 15 words, verb 15 words, adjective 5 words, adverb 5 words, pronoun 7 words, preposition 2 words, conjunction 1 word, interjection 6 words. The research concluded that the development language acquisition of child 2 years old depend on level of communication in daily communication and also environment.

\section{CONCLUSION AND SUGGESTION}

Based on the results of the data and discussion of research on language acquisition of the child four years old named Beryl Ibrena Barus for analyzed kind of words noun 5 words, verb 3 words, adjective 5 words, adverb 2 words, pronoun 2 words, preposition 1 words, conjunction 1 word, interjection 6 words.

The obtained of language acquisition, the research subject was affected by 
natural factor, input and social background. This natural factor was also influenced by input and social interaction. By obtain the input he could get acquired a new word and increase vocabulary, that he could master the language. The research subject got the input from the environment, for example, his parents, other family, people around him, devices (Television and Smartphone) Social background of the research subject also affected him in acquire the language acquisition. Generally, the people around the research subject were children and good people, so he could get a good language. The child imitated the words, sounds, and some actions of people around him. The researcher could conclude that development language acquisition of child 4 years old different depend level of communication, intelligence of child in daily communication and environment. The fact may be different if children are taken from other children or from different ages

For advanced researchers, this research only discusses about language acquisition of kosa kata Bahasa Karo of four year Karonese child, another researcher may discussed this research clearly. The researcher hopes this research can inspire other researchers who want to conduct further research about language acquisition of kosa kata Bahasa Karo. The researcher also hopes this research can give information to the readers about language acquisition of kosa kata Bahasa Karo of four year Karonese child. 


\section{REFERENCES}

Clark. Eve V 2003. First Language Acquisition.

Clark and Herbert H. Clark Eve, V. 1977. Psychology and Language: An Introduction to Psycholinguistic. USA: Harcourt Barce Jovanovich, Inc.1977. Psychology and language. New York: Hartcourt Brace Jovanovich.

Hatch, E., \& Brown, C. (2001). Vocabulary, Semantics, and Language Education. New York: Cambridge University Press. Hill, M.

Scovel, Thomas. 1998. Psycholinguistics. Spain: Oxford University Press.

Skinner.B.F (2013). Ways of Learning: Learning Theories and Learning Styles in the Classroom. London: Routledge

Steinberg Danny D.( 1993.) . London: Longman, Studies in Second Language

Towel , R . and Hawkins , R . ( 1994 ). Approaches to Second Language Acquisition . Clevedon : Multilingual Matters .

Van Petten, Bill William, jesica . 2015. Second Language Acquisition Research, Theories In Second Language Acquisition.

Varshney, R. L. (2003). An Introductory Textbook of Linguistics \& Phonetic. India: Student Store. 